\title{
Bones of Contention in Uzma Aslam Khan's The Geometry of God
}

Pascal Zinck

\section{(2) OpenEdition \\ 1 Journals}

Electronic version

URL: https://journals.openedition.org/ces/7869

DOI: $10.4000 /$ ces.7869

ISSN: 2534-6695

Publisher

SEPC (Société d'études des pays du Commonwealth)

\section{Printed version}

Date of publication: 1 September 2011

Number of pages: $43-53$

ISSN: 2270-0633

\section{Electronic reference}

Pascal Zinck, "Bones of Contention in Uzma Aslam Khan's The Geometry of God", Commonwealth Essays and Studies [Online], 34.1 | 2011, Online since 16 November 2021, connection on 01 December 2021. URL: http://journals.openedition.org/ces/7869 ; DOI: https://doi.org/10.4000/ces.7869

\section{cc)}

Commonwealth Essays and Studies is licensed under a Licence Creative Commons Attribution - Pas d'Utilisation Commerciale - Pas de Modification 4.0 International. 


\section{Bones of Contention in Uzma Aslam Khan's The Geometry of God}

Recent upheavals in the Arab world are far more likely to have been triggered by the impact of globalization on autocratic regimes than by the doctrine of the "clash of civilizations." Uzma Aslam Khan's The Geometry of God probes similar fractures undermining Pakistani society along religious/secular, civil/military, urban/rural or autocratic/democratic lines. This paper examines how in Khan's novel Pakistan addresses the different challenges of modernity, or more precisely, how Islam struggles to maintain its hold on a growing secularized society. It also highlights the oppression of women with the legacy of General Zia ul-Haq's islamization policy of chadar aur chaardhiwaaree ("the sheet and four walls").

The post boat was like a gondola

that called at each houseboat. It

carried a clerk, weighing scales,

and a bell to announce arrivals.

$[\ldots]$ Portents

of rain, rumors, ambushed letters...

Curtained palanquin, fetch our word,

bring us word: Who has died? Who'll live?

Has the order gone out to close

the waterways... the one open road?

Agha Shahid Ali, "The Floating Post Office”

The magnitude of the $9 / 11$ shockwave that rocked America registered as a new Pearl Harbor. This seismic event marked a major shift in US foreign policy and national security. However, according to international policy analyst Edward Haley, the Global War on Terror or GWOT is the cumulative effect of many collisions on the Richter scale of foreign policy, all of which were triggered off by flawed post-Cold War assumptions and strategies (1; see also Brzezinski and Scott). Along the same lines as Haley, Khaled Hosseini draws on tectonics to comment on the endless chaos decimating Afghanistan (287-8). The theory of plate tectonics can thus shed light on the crises and collisions of globalization. This theory developed out of the concept of continental drift expounded by Alfred Wegener, according to which the continents slipped through the oceanic crust under the influence of gravitational and rotational forces. As Gillian Beer notes in "Discourses of the Island," the emphasis in plate tectonics is on fracture, drift, the lateral slide or collision of plates (8). Far from being considered as one rigid, monolithic body with fixed continents, the earth's outer shell, or lithosphere, is a highly complex and heterogeneous structure divided into a number of large and an even greater number of secondary and tertiary plates forming a mosaic of separate jostling blocks of different shapes and sizes, generally a few hundred kilometers across (Chekunov, Gordienko and Guterman 404). Beer draws an insightful parallel between the processes of unfixing and slippage that buttress the theory of plate tectonics and the Derridean idea of epistemological "ungrounding" or 
differance. When transposed as a concept to interpret the construction of cultural meaning in national contexts, plate tectonics functions, like différance, to epitomize the intrinsic instability, the ever "deferred," shifting configurations of national and cultural identities. Within this critical framework, and focusing on the tension between radical Islam and rationalism, as well as on poetics of dissent, I shall examine The Geometry of God (2009) by Uzma Aslam Khan, a story of paleontological investigation set in Pakistan.

Khan's plot structure presents a similarity to Anil's Ghost. Michael Ondaatje's eponymous narrator conducts an international investigation into human rights abuse in her native Sri Lanka. Against the odds, and despite government efforts to sabotage her mission, she manages to identify one of the countless victims of extra-judicial killings and to restore dignity to the disappeared. Similarly, in The Geometry of God, the field studies that paleontologist Zahoor ul-Din undertakes into the limestone sediments of the Margalla Hills - "what was once a sea called Tethys" (2) - do not only yield fossils of Pakicetus, a protowhale which is believed to provide clues as to how the descendants of an ancestral species might have evolved into different forms, splitting into separate lineages. His findings also cause a chain reaction leading to fatwās, denigrating both scientific inquiry and intellectual engagement, and threatening to damage the very fabric of Pakistani society.

In a novel spanning over twenty years, from General Zia's embracing of Islamization, referred to as Nizam-e-Mustafa, in 1978, to the toppling of Nawaz Sharif's government and the emergence of Pervez Musharraf in the early $21^{\text {st }}$ century, Zahoor ul-Din stands out as a latter-day Darwinian patriarch whose entire energy is mobilized to solve the jigsaw puzzle of creation, epitomizing man's indefatigable quest for knowledge. There is abundant fossil as well as sediment evidence that the Tethys Sea in the region of the present Himalayan orogenic belt was not a deep, wide ocean but rather a narrow, predominantly shallow, intracontinental seaway. Contrary to Creationists and the exponents of Intelligent Design, Zahoor's methodology succeeds, like Darwin's, because it incorporates randomness, trial and error, what he calls "accidental stages" or "fluke encounters" (111), owing to the unlikely presence of fossils on a hillface instead of at the bottom of the cliff or underground.

Based on such evidence, Zahoor's international team plans a campaign of further digs to test the validity of their hypotheses, particularly about the continental drift and subduction/collision models - the uplift of the Himalayas and the Tibetan Plateau by the collision of the Indian plate with the Asian plate. Their findings are published in an article entitled "The Blueprint for Life," which is reviewed in the US and presented in an open contradictory debate. Quoting Aristotle, al Kindi, Ibn Sina (Avicenna), Ibn Rushd (Averroes) and Pascal, the old paleontologist lectures his audience, particularly his detractors, about the gift of infinite curiosity. These references are not coincidental: they help contextualize the current epistemological and ideological debate on the (in)compatibility of science and religion, and vindicate falsafa (Brague $100,130,254,273-5)$ as well as the Mu'tazilite enlightenment. ${ }^{1}$

1. Falsafa refers to the Aristotelian philosophic legacy in the Muslim world. Mu'tarilab designates a Muslim theological school admitting rationality which prospered in Iraq between the $8^{\text {th }}$ and $10^{\text {th }}$ centuries and waned in the $15^{\text {th }}$ century, after vehement attacks from traditionalists on the one hand and from the atheists, deists and philosophers, on the other. 
Zahoor recognizes a talent for inquiry in Amal, the independent-minded granddaughter he has helped educate. Symbolically he offers her his old microscope a gift which seems to coincide with the first attacks by his detractors. As a fatwā is issued against the avuncular scientist who is first banned from teaching, then sacked from the University, later to be arrested and put on trial, Amal, whose name means both hope and labour, is left to take up the mantle of scientific exploration and find another "diamond key" to complete the "Tree of Life" (132) — in other words the evolutionary mapping out of all related species through time. It is therefore no surprise that Zahoor dies when his granddaughter fulfills her promise. Confronted with the very puzzles that mobilized her grandfather, the young paleontologist chances to excavate skeletal remains of Cornucetus, a missing protowhale.

The novel's other polar axis is represented by Mirza Inayat Anwar, the vicechairman of Jaamiat-e-Pedaish (JeP), the "Party of Creation," a hybrid of fundamentalist organizations like Jamiaat-e-Islami, Jaish e-Mohammad (Army of the Prophet), and Aalmi Majlis Tahaffuz Khatm-e-Nubuwwat (Movement for the Finality of Prophethood, or $\mathrm{PBUH}^{2}$ ). General Zia ul-Haq, Pakistan's erstwhile dictator, was present at the launch of the party, and Zahoor ul-Din has misgivings over the unholy alliance between tanks and mullahs. Unlike Zahoor's universalist motto, "the world is my Ka'ba" (7), both Jaamiat-e-Pedaish and its offshoot, "the Academy of Moral Policy," see everything gravitate around the Ka'ba, the house of God in Mecca. Accordingly, Jaamiat-e-Pedaish pursues a radical religious agenda based on strict observance of Shariat, the Islamic moral code and religious law based on the Quran, and consistent with Salafism or Deobandi Sunnism.

Underpinned by fear of youth which fundamentalists consider as deviant or "freak" (83, 98), by obsession with sexuality, by mistrust of cultural encounter and intellectual debate, the party's Islamization programme is articulated in the same hotel in which the paleontologists present their findings. 'The movement's exclusivist core values are Al Sirat al Mustaqim, that is to say "the straight path," or "The True Path," and maghrib za'dagi, or westoxification, the need to extirpate kaffir ideas and values which contaminate the "real Pakistani" (80, 83). As a result, Jaamiat-e-Pedaish proselytizes in madrassas or Islamic schools, promoting radical Islamic indoctrinationobservance of prayer, haram and fasting during ramadan, obedience to patriarchal order, segregation of women and suppression of secular contestation.

In Husband of a Fanatic, Indian writer Amitava Kumar denounces the rewriting of national texts, particularly school curricula, as a key component of fanaticism. In their misguided nostalgia for wholeness and for roots, hindutva fundamentalists "refashion the past by wilfully denigrating Islam or destroying its historical claims" (Kumar 120), for instance the delusional provocation that the Taj Mahal is in reality Tejo Mahalya, an ancient Hindu temple dedicated to Shiva (254). In similar revisionist fashion, in The Geometry of God, fundamentalists indulge in a puritanical scripting of Pakistan, removing pagan or Hindu features from the country's face. Noman, the son and pen of the vice-chairman of Jaamiat-e-Pedaish, is instructed to propagate the idea that,

\footnotetext{
2. The acronym standing for Peace Be Unto Him is the standard reference for the Prophet.

3. Note the language of contamination, espionage or disease (123).

4. Hindutva meaning hindu ultranationalists.

5. This example is also quoted by Khan (71).
} 
contrary to historical facts, Pakistan was not created as a result of Partition in 1947, but "discovered by Bin Qasim in 712" (134). In the same vein, the dutiful scribe doctors one of Jinnah's foundational speeches, supporting the interpolation by a secular state of both Islamist ideology, and Muhammad Iqbal's theocratic and exclusivist views (38-9).

Revisionism permeates Akblaq, the monthly journal published by the Academy of Moral Policy. According to Noman's mother, the title combines akblak meaning ethics and khalq, creation. The overriding objective of the publication is to silence and terrorize both scientists and secularists. "The Blueprint for AFTERLIFE" refutes the materialist worldview represented by the Darwinian theory expounded in Zahoor ulDin's "The Blueprint of Life" on the premise that divine orthodoxy cannot be challenged. Here Uzma Aslam Khan draws ironical parallels with Ibn Rushd's Tahafut al-tabafut (The Incoherence of the Incoherence, circa 1180), a rebuttal of al-Ghazali's misinterpretation of Aristotelian philosophy in Tahafut al-falasifa (The Incoherence of the Philosophers, dated 1095). The message of Intelligent Design or "Pure Science," which Zahoor dismisses as "Deiformity" (Khan 26), is not only meant to expurgate Archimedes, Newton, Darwin, Mendel, Howard and Einstein, in consonance with Harun Yahya's (Adnan Oktar's) theistic Atlas of Creation (2007). ${ }^{7}$ Its agenda is to combat a global conspiracy against the ummah (the Muslim community) as well as to collect funds from Saudi or American benefactors. At international conferences, debates on $A$ l Islam $W$ al 'Aoulama (Islam in the context of globalization) are tolerated, but exponents of a compromise between science and moderate Islam are ultimately shouted down. In other words, the sole objective of Jaish-e-Pedaish is to propagate a binary division of the world into dar al-Islam (the abode of Islam) and dar al-harb (the abode of war), in a reductive worldview which is the converse of President George W. Bush's "axis of evil" rhetoric.

The situation escalates in Islamabad as Zahoor caused outrage after making God the subject of a multiple choice questionnaire: "If God is perfect why did he make us? The choices are a. There is no God. b. He is also flawed. c. We are perfect" (Khan 175). Jamaat e-Pedaish trumps up charges against the old academic after issuing him with a fatwā, and has him first banned from teaching at the University, then arrested and tried pursuant to Section 295-B of the Blasphemy Law (defiling the copy of the Holy Quran) as well as Section 295-C (defiling the sacred name of the Prophet Muhammad, PBUH). The accusation includes several counts - defiling the Prophet, burning pages of the Holy Quran, as well as insinuations that Zahoor is an Ahmadi

6. Muhammad Ali Jinnah (1876-1948) and the poet Muhammad Iqbal, also known as Allama Iqbal (1877-1938) were instrumental in the creation of the Islami Jumburiyah Pakistan, the Islamic Republic of Pakistan. Jinnah, who presided over the Muslim League and served as Pakistan's first president, is regarded as the Quaid-i-Azam, the nation's Great Leader. Revered as Muffakir-e-Pakistan (the Thinker of Pakistan), Iqbal was critical of the separation of Church and State in the West and he imposed the idea of a Muslim State for the Muslims of the sub-continent, on the basis of Sir Sayyed Ahmad Khan's two-nation theory at the end of the 19th century. The name Pakistan was coined by Choudhry (Chaudhry) Rahmat Ali in a 1933 pamphlet as the land (Stän) of the pure (Päk). The name was also an acronym for the Muslim territories: P for Punjab, A for Afghania, K for Kashmir, I for Indus-Sind and Balouchistan for the stan suffix (Ali 1947).

7. The Turkish exponent of creationism invokes the fact that fossils emerged with all their complex structures and features perfectly similar to their present day analogues' to demonstrate that evolution is an imaginary process or a hoax and that all living things were actually created by God. 
and a heretic who had written the names of the caliphs on the soles of his feet. ${ }^{8}$ The charge for his alleged blasphemous transgression (Badd al-rasool) is the death penalty. ${ }^{9}$ Even his defence counsel equivocates over his "heresy" and advocates a plea for insanity. Whether remanded in custody or discharged, the targets of Blasphemy Laws are often executed in prison or face mob lynching on the incitement of imams. In a matter of a few days after Zahoor's acquittal, two of his guards are killed with an ominous note: jaise ap ko pata hai (as you know [324]). Then the terrorists assassinate successively the judge's and his lawyer's guards with further grim warnings: jaise ap ne dekha hai (as you have seen [325]) and jaise ap ne suna hai (as you have heard [325]). Zahoor becomes al ghayb, the absent, a living dead awaiting his death squad.

The novel's ideological underpinnings map out relationships that dichotomize conflicts into right/wrong binaries resonant with Samuel Huntington's Clash of Civilizations and discourses of othering. Far from subjecting the reader to an arid confrontation between the Darwinian and creationist/Islamist worldviews, the novel mediates the debates and tension with a combination of immediacy and detachment. ${ }^{10}$ Indeed, although Zahoor ul-Din and Mirza Anwar argue the merit of their respective cases, neither is a narrator. Instead, the narrative is unevenly distributed over a twentyyear span among Amal, Mehwish and Noman, three children/teenagers/young adults whose respective voices are heard in fifty-five fragments arranged into five sections called "gateways." Khan has crafted a complex narrative structure with similar events revisited from different perspectives and witnesses, subverting chronological order and linear coherence with analeptic and proleptic segments that slip and collide against one another with ripple effects, recalling the bullets that ricochet against the walls before entering the bodies of Noman and Mehwish.

Another decentering technique deployed by Khan is shape-shifting. Noman, who as a teenager had a taste for ladies' 42C lacy cups and a penchant for Johnnie Walker, disconcerts a foreign journalist by refusing the assigned role of an aggrieved "real Muslim":

She wasn't satisfied. "You're a Muslim?"

Wish she'd put the question to Zahoor. Never thought I'd have to confess my faith. Say it! Say it! I smiled into the camera and asked if she works for the Party of Creation.

"I don't have much time. Are you a real Muslim?"

"No, imitation." (369)

This admission of duplicity is in keeping with both his apostasy as he resigns from the editorship of Akhlaq and his role as agent double, or as he puts it himself as "match fixer," "batting for both sides" (141). Khan's artful informer resembles Shahid, the narrator of Hanish Kureishi's The Black. Album who is recruited into a radical Islamic group. Riaz Al-Hussain, the uncharismatic leader, entrusts the young student with editing his militant poetry. Shahid finds the exercise utterly uninspiring and instead subverts the wooden text with his own erotic interpolations.

8. Under General Zia's military rule, the Ahmadi sect was denied the right to call itself Muslim, a prohibition that still has not been repealed.

9. The trumped up charges against Zahoor are reminiscent of the death sentence on similar counts handed down to Asia Bibi, a Christian, for drinking from a communal well in a Muslim village and thus allegedly polluting the water.

10. For a less nuanced treatment of the debate between fundamentalism, moderate Islam and secularism, see Khuda kay Liye and Shoot on Sight: Is it a Crime to be a Muslim? Both Mansoor's and Mundhra's films have their westernized protagonists struggle against radical Islam and Mansoor incurred a fatwā on the release of Khuda kay Liye. 
Apart from the leader entitled "al Qalam," "11 which contains both a denunciation of fanaticism and an ethical wake-up call, the last issue Noman edited is a provocative collage of a poem by Mir Taqi Mir - "To save their souls they kill themselves with care / A Paradise like that can go to Hell!" (301) - a sketch of a crocodile-rat called My Landlord, a snapshot of a barber, other photographs of roofs and of a crossdressing friend. Noman's late rebellion as his father's pe(o)n echoes his avid clandestine readings of Mu'tazilites as well as Darwin, and even his undercover philosophical disquisitions with Zahoor.

Uzma Aslam Khan's clever use of pastiche to subvert orthodoxy and hegemonic discourse should be emphasized. Staring at the blank page and terrorized at failing to meet criteria and deadlines for his father's sectarian publication, Noman enlists the cooperation of his mother who proves an expert at decoding fundamentalist doctrine and parodying Manichean sophistry:

"Write about the meaning of the magazine's name, Akblaq."

"Great idea!" [...] "What does it mean?"

She shakes her head. "Why are you so foolish? Can't you guess? It means ethics. It has the same root as khalq. Creation. Write that."

So we start this perfect introduction:

Virtuous behavior (akhlaq) cannot be separated from a proper understanding of the purpose of creation (khalq). It is an issue as much of morality as [took forever to find the word] cosmology. Scientific thinking blurs the relation between the two by insisting on a world of "facts." The purpose of our movement and of this magazine is to return us to the path of the humble salmon that follows divine laws not fickle experiments, and not transitional change (see appendix, What Only Allah Sees, by Ali Abidi, Ph.D). (107)

"The Blueprint for AFTERLIFE" synthesizes the case against scientific advancement:

Proponents of this science are men like Zahoor ul-Din, who obscure the true message of Islam, making it a puzzle full of hidden metaphors and poetry, twisting it this way and that, and generating great support for themselves. But they are themselves blind and the blind must create what they cannot see. The seeing, who adhere to their Shariat, are gifted with a "third" eye. We see Divine Proofs Revealed. We have lifted the veil from our eyes. We need not "interpret" or even "read." We see ALL, the visible and invisible, angels and djinns. (137)

In his pamphlet Noman is ascribed to rewrite history, particularly Islam's medieval philosophical and scientific thinking which rationalists like Zahoor countenance. The pamphlet seems so seamless a fabrication that Noman cannot believe he has penned it unassisted. The metaphor of visibility/invisibility is both felicitous, given the ideological context, and ironical as the counterfeiter falls in love with Mehwish, the blind granddaughter of his would-be archenemy. The dichotomy of "we" (the ummat al-mu'minin) versus "them" (the deviants or kaffirs) characterizes Manichean discourse. This process of alienation complements the elision of the subject mentioned earlier as Noman is challenged by a US reporter about his religion. At the zenith of his counterfeiting prowess, Noman confesses that he has lost his sense of self and that he is literally a mere mouthpiece, his master's voice:

11. Kalam (literally "speech" or "words") is the Islamic philosophical discipline of seeking theological principles through dialectic. 
Who taught me to believe Aba wrong and prove him right? I've come full circle. Or crashed. I can argue anything. I have no beliefs of my own. Light and darkness negate each other. The ions of my mind are in deep freeze. Meet Noman, who is an island. Not a synthesis, or even a cultural freak. But an absence. (137)

Pastiche is not the only strategy Khan uses to dismiss radicalism as badly regurgitated politicized theology. Heteroglossia and the subversive use of language also play a key role. Given its fluidity and multi-layeredness, language defies the exclusivist discourse on purity, as Mehwish retorts to Nana (her nickname for Zahoor) that a ghazal in English is illegal: "A language is like a whale it comes from something else. Urdu from Persian, Hindi and Arabic" (189). Owing to her blindness, Mehwish learns rudiments of English through phonetic or tactile Braille recognition - her sister Amal who takes on the mission of being "her eyes" teaches her to feel the "positives" and "negatives" of letters, words and short sentences pressed on the front and embossed at the back of a page. ${ }^{12}$ She also uses pottery shards and toothpicks as Braille language and even scrawls words on her sister's back at bath time for her to draw in mirror image. As a result, Mehwish develops a playful idiolect based on mimicry and phonic interpretation: "Nana says young pee pull get stupider every day and maybe he is right big cause the air is very dirty. This is called pull ocean which is different from pull nation which is what bees do not slugs" (159).

Mehwish's reconstituted idiolect is traversed by fracture zones as she fragments or truncates language. Here are a few examples of syntactical blocks which jar and jostle against one another to defy logic in a kind of verbal hopscotch and build up new clusters of meaning: "hic cup," "pee pul," "inty messy," "konk west," "miss takes," "bore dum," "pam flit," “meta-firs," "promiss kiss," "sis tim," “dizz aster," "sir wival," "crip tick," "anth-ro-po-more-fies-ing," "pale into logic," "me link holy." She may be unaware of the impact and import of many of her phonic splits to a certain extent, yet she is a receptacle and echo chamber of her subversive elder sister, Amal. Thus, her hyphenations tend to reflect a certain disregard for authority and orthodoxy: "Dog ma," "sin a men," "a her tick," "sir whale ants," "dead lock," "mince trees," "diff cult," "oxen moron," "[the] dead lit rilists" or "dead literalists" in reference to the zealots of apocalyptic superstition and literal reading of the Quran epitomized by Jamaat e-Pedaish or Miss Fauzia, the disciplinarian who is hell-bent on policing language as well as confiscating drawings.

To contest her repressive teacher's narrowly defined boundaries, Mehwish also resorts to humour, particularly punning. She would readily consign the ramrod hardliner on board a plane with the "[moon] Sighting Comedy," in relation to the Moonsighting Committee Worldwide in charge of calculating the beginning of ramadan. ${ }^{13}$ The implication is that Miss Fauzia's paranoid reliance on religion amounts

12. Through Amal's agency, Khan exploits nonverbal communication through all sensory channels, more particularly sight, touch and taste. Amal "somatizes" the land, feeling the salty tang of the fossil strata of Tethys. She coaches her blind sister through haptic communication and informs her about the way space is gendered (cf. the rape attempt). Body language includes the transgressive exploration of sex and the expression of eroticism. Mehwish, whose eyesight has been damaged after exposure to light, also relies on touch, voice, vocalization and proxemics.

13. See Khan 188, 204, 206. Ramadan is the ninth month of the Islamic calendar. It lasts from twenty-nine to thirty days. As compared to the solar calendar, the dates of Ramadan vary, moving backwards about eleven days each year depending on the moon. There is a debate among the Muslim community on just how to calculate the beginning of the month of Ramadan (or indeed any month, but Ramadan takes on special importance as it is the Islamic month 
to witchcraft. Mehwish supplies further evidence of her transgressive humour when she misreads God in Braille for "Clog," "Clod," or even "Clue" (205-7), approximations which are not as innocuous as they sound given the novel's context. This interpretation is supported by Miss Amna, a more sympathetic and liberal teacher who warns her young pupil against antagonizing orthodoxy. Henceforth, and as she gradually outgrows her childhood idiolect, Mehwish keeps "Clog" to herself as a kind of trusted confidant following Amal's emancipation.

As an alternative to her verbal hopscotch and her induction in Braille, Mehwish develops a sophisticated cipher. Modelled on Mendeleev's periodic table of elements, her "Periodic table of Stinks and Sounds" is a tabular display of fourteen boxes of different sizes in vertical columns numbered from zero to nine (there are four empty boxes). ${ }^{14}$ Each box is encoded with a capital letter standing for a name and followed by a list of symbols reflecting the character's name. Thus Miss Fauzia, the disciplinarian, is assigned number zero in the bottom central box, so as to contain her negativity. She is uniquely deprived of a code letter, and her list includes the respective words "Toilet" and "Target practice" in relation to her smell and her snooping and cracking down on dissent, while the term "Djinn atoms" refers to her religion. Conversely, Zahoor appears in the first inscribed box, in the right-hand column, numbered one and affixed with the letter $\mathrm{N}$ (for Nana, his nickname). His list contains the colour Red, in reference to his leather slippers and his firebrand enthusiasm and rebellion. Not only does Mehwish design her table for keeping secrets as well as pidgeon-holing censors, but the layout which evolves to register mutations and new affiliations provides the growing teenager with a private space commensurate with her sister's emotional and sexual emancipation.

To compensate for Amal's estrangement as well as Noman's ideological disquisitions with her grandfather, Mehwish spends more and more time composing poetry with Zahoor, particularly love poems. She draws an interesting parallel between the playfulness and subversive power of the ghazal and the resourcefulness of her Table. In both cases, she has to operate within the constraints of the form - the restrictions of the boxes or the monometre and monorhyme of the ghazal - but the rules are there to be transgressed and subverted or perverted, toyed with. The ghazal is a lyrical poetic genre, whose literal meaning from the Arabic word ghizaal for gazelle is "to converse with the beloved," emanated from the Sufi centres, and was subsequently cultivated by court poets (Russell 1992). ${ }^{15}$ Formally, the ghazal is a series of between five and twenty-five rhymed couplets called shers or ashaar, which follow the rules of kaafiyaa, radif, matla, maqta and beher consistently throughout the poem.

From the second couplet onward, the second line of each couplet follows the pattern of rhyme - kaafiyaa - and refrain - radif or radeef - established in the matla or opening couplet. The last verse of the ghazal (maqta) usually contains the poet's signature. All the verses must be of the same meter (beher). The ghazal is ideally suited

of fasting). This stems from the tradition to see the slight crescent moon (bilal) with the naked eye. Hence the differences for countries on opposite sides of the globe.

14. Symbolically, Mehwish's Periodic Table coincides with her awareness of changes within her own body menstruation - and Amal's sexual emancipation.

15. Courtly love often involved "illicit love," "the love of a man for another man's betrothed or another man's wife" (Russell 35). 
to Zahoor as it allows for both adherence to the form and playful deviation or contestation. Double entendre is the hallmark of the old man's "legal ghazal" which occupies a central place in the novel and acts as its miniature mirror image reflecting on life's contingencies and human nature. The oxymoron is highly significant given the old man's precarious legal status and his lifelong commitment to challenging rigid boundaries. The poem is mediated through Mehwish's voice, hence the splits and the interplay between the linguistic blocks:

\section{The world belongs to who ever takes it; it will change \\ The trunk of a road, the fluke of a toad, the seat of a court; \\ it will change [...]}

The slant of a bill the depth of a sea the eye of a bee, life is flux

A boy with no socks in a little girl's box; it will change

When girls dig bidden whales they pre wail,

When adults get in their way they fail; it will change

$A$ bone not revealed but created

A book not preserved but confiscated; it will change

A prayer unheard is not without creed

A land unfree is destined to bleed; it will change [...]

\section{But there's an other wise a way the heart waits dif eyes time and stays true}

Quite simple it is, wise and won deris, in loving You there is only one rule; it will not change. (190-1)

The target of the poem is religious reactionaries and fundamentalist interpretations of religion, which tend to essentialize history into binaries and oppose change, evolution or hybridity. Ghazal is the soul of Urdu literature and the most popular form of Urdu and Persian poetry. It is no coincidence that Zahoor should quote Iqbal Bano (1935-2009) and Faiz Ahmed Faiz (1911-1984), two late 20th-century ghazal voices, both of whom fell foul of General Zia's military rule. ${ }^{16}$ We should not interpret the choice of English as a betrayal - Agha Shahid Ali, who is quoted in the epigraph to this article, has demonstrated that English can render the convexities of Mughal art despite Kashmir's climate of fear and fragility - but as a further gesture of resistance which Zahoor justifies as illegality. In another non-standard ghazal apparently inspired by Mehwish's Clog, Zahoor makes an explicit link between communal intolerance, the Blasphemy Laws and the colonial legacy. The lives of present-day Pakistanis are still governed and policed by an antiquated British code that reads like Braille but can nonetheless mete out the harshest of sentences, including capital punishment (234-5).

The Geometry of God articulates the tension and frictions linked to the context of modernity, secularism and Al Islam Wal 'Aoulama - Islam's engagement with globalization. Resistance to fundamentalist, exclusivist discourses come at a cost as the

16. Iqbal Bano was a highly acclaimed Ghazal singer from Pakistan. She was best known for her semi-classical Urdu ghazals and classical thumris, as well as 1950s film songs. Bano roused a strong crowd of 50,000 people in Lahore by singing Faiz Ahmed Faiz's passionate Urdu anthem, Hum Dekhenge, although his works were banned under General Zia ul-Haq's military regime. She also sang ghazals by Nasir Kazmi as well as ghazals in Persian. 
words "upheaval," "tsunami," "chaos" indicate $(339,348,351)$ and as the tragic deaths of Zahoor and of his Sufi friend, Junayd, exemplify. It is often women like Noman's mother, Amal or Mehwish who bear the brunt of the othering processes and yet find the resilience to bridge the gaps, to mediate intersections between faith and love. ${ }^{17}$ Uzma Aslam Khan subverts the notion of a monolithic text, of static and ossified male-centered, radical religion-based identities. Her multi-layered novel which combines prose, poetry, drawings, boxes and chart is a hybrid of English, Urdu, Punjabi, Arabic and Latin sediments; as such it deflates and defeats the paranoia of the purists and the puritans. Khan reminds her reader of the syncretism of Lahore, a palimpsest of histories and religions. Noman, who has become a mathematician while retaining Zahoor's philosophical legacy, chooses the geometrical instability of the "sifr," the magic zero, over the neat ordering of Euclidean space: "on other days, the pattern offers no revelation. I gaze at the ceramic sky, with its floating red and black clouds, searching for a way to connect point, line, and space, to reach that elusive center" (74; see also 339). By the end, Noman gains an identity - free from biological constraints, he has become Zahoor's specially created son in lieu of his biological father who has disowned him and has expanded gateways "from square to circle to triangle" (338). Claiming the original bones of the species becomes irrelevant. Noman has regained his identity despite the Islamic genie that his father unloosed, despite the "collateral damage" to his friends and to himself - as he has to live in a post-Islamist world with a bullet lodged near his heart

Pascal ZINCK, Université Lille 3

\section{Works Cited}

Al, Agha Shahid. "The Floating Post Office." The Country Without a Post Office. New York: Norton, 1997. 52.

Ali, Choudry Ramat. Pakistan: The Fatherland of the Pak Nation. Cambridge: National Liberation Movement, 1947.

Aslam, Nadeem. The Wasted Vigil. London: Faber, 2008.

BAuman, Zygmunt. Liquid Modernity. London: Polity, 2000.

BEER, Gillian. "Discourses of the Island." Literature and Science as Modes of Expression. Ed. Frederick Amrine. Amsterdam: Kluwer, 1989. 1-27.

Brague, Rémi. Au moyen du Moyen Agge: Philosophies médiévales en chrétienté, judaïsme et islam. Paris: Flammarion, 2008.

BrZEZINSKI, Zbigniew. The Grand Chessboard: American Primacy and its Geostrategic Imperatives. New York: Basic, 1997.

Chekunov, Anatolii, V. V. Vasilevich Gordienko, and V. G. Guterman. "Difficulties of plate tectonics and possible alternative mechanisms." Critical Aspects of the Plate Tectonics Theory. Ed. A. Barto-Kyriakidis. Athens: Theophrastus, 1990. 397-433.

HALEY, Edward P. Strategies of Dominance: The Misdirection of U.S. Foreign Policy. Baltimore, MD: Johns Hopkins UP, 2006.

HosseinI, Khaled. A Thousand Splendid Suns. London: Bloomsbury, 2007.

Huntington, Samuel P. The Clash of Civilizations and the Remaking of World Order. New York: Simon and Schuster, 1996.

IBN RUSHD [AvERROES]. The Incoherence of the Incoherence (Tahafut al-tahafut). Trans. Simon van den Bergh. Cambridge: Gibb Memorial Trust, 1954.

KHAN, Uzma Aslam. The Geometry of God. Northampton, MA: Clockroot, 2009.

Khuda kay Liye. Dir. Shoaib Mansoor. Geo Films and Shoman Production (Pakistan), 2007. 168 min. 
Kumar, Amitava. Husband of a Fanatic. London: The New Press, 2005.

KureISHI, Hanif. The Black Album. London: Faber, 1995.

Russell, Ralph. "Understanding the Urdu Ghazal." The Pursuit of Urdu Literature: A Select History. London: Zed, 1992. 26-52.

Sсотт, Peter Dale. The Road to 9/11: Wealth, Empire and the Future of America. Berkeley: U of California P, 2007.

Shoot on Sight: Is it a Crime to be a Muslim? Dir. Jag Mundhra. Aron Govil Productions (India), 2007. $110 \mathrm{~min}$.

Yahya, Harun [Adnan OKTAR]. Atlas of Creation. Istanbul: Global Publishing, 2007. 